\title{
COMMENTARY
}

\section{The Moral Economy of Fertility Markets: Hope and Hype, History, and Inclusion}

\author{
Seema Mohapatra and Dov Fox
}

$\mathrm{B}$ rigitte Adams is the founder of Eggsurance. com who froze her own eggs in her late 30 s (for $\$ 19,000)$. In 2014, she posed for a Bloomberg Business cover story: "Freeze Your Eggs, Free Your Career." Put childbearing on ice to level the playing field and open opportunities at work. ${ }^{2}$ When Adams tried to use her own frozen eggs at 45 , however, she was unable to get pregnant. Adams is "still positive about egg freezing," but "not positive about how it's being marketed."

Michelle Bayefsky argues that fertility companies mislead millions of American women, including the $10,000+$ who have paid to freeze their eggs. ${ }^{4}$ She makes the case that corporate claims to "stop time" or "freeze fertility" - while stopping short of explicit assurances - still cross the line of informed consent and truthful advertising. Her analysis of this landscape adds critical evidence to calls for transparency in the multi-billion-dollar market for reproductive services. ${ }^{5}$

Egg freezing ads focus on choice and control. But the science is out on how reliably frozen eggs result in live births. Individuals and couples who roll the dice for a chance at biological parenthood are entitled to know the risks and benefits going in. But misleading claims risk preying on the dreams that egg freezing can make possible, leaving too many with overblown expectations and no legal recourse.

Seema Mohapatra, M.P.H., J.D., is Associate Professor of Law and Dean's Fellow, Indiana University Robert H. McKinney School of Law Dov Fox, L.L.M., J.D., D.Phil., is Professor of Law; Herzog Endowed Scholar; Director, Center for Health Law Policy $\sigma^{\circ}$ Bioethics, University of San Diego School of Law.
These arguments revive old questions about advances in reproductive freedom and the fraction of society who can take advantage of its newest forms. ${ }^{6}$ This reflection gestures toward two issues that Bayefsky does not take up: (1) history and (2) access. Neither omission diminishes the force of her findings. But both provide essential context for appreciating its full implications.

First, we have been here before. American fertility clinics have long overstated people's chances of taking home a baby by using criteria such as the number of eggs retrieved and number of embryo transfers, rather than the number of live births. ${ }^{7}$ Some have even sought to signal success rates by offering splashy money-back guarantees (albeit ultimately to a fraction of uniquely low-risk patients). ${ }^{8}$

Public outrage over inflated fertility clinic success rates brought federal and state regulation in the early 1990s. ${ }^{9}$ But it wasn't enforced. By 1996, an American Medical Association report found that "deceptive advertising and insufficient informed consent" were rampant in assisted reproduction. ${ }^{10}$ Bayefsky isn't the first to show such marketing still wants for clarity and candor. The New York Times ran a recent profile on the fertility industry's "Misleading Promise to Those over 40."11

The only federal regulation doesn't do enough. A 1992 law asks clinics to report how often IVF patients get pregnant. But there's no penalty for failing to comply. ${ }^{12}$ And it's unclear whether consumers seek out this information anyway. Bayefsky calls for oversight by the Federal Trade Commission. But she misses deeper anxieties - from across the ideological terrain - that help explain the FTC's longstanding indifference to fertility markets. ${ }^{13}$ 


\section{Michelle Bayefsky argues that fertility companies mislead millions of} American women, including the 10,000+ who have paid to freeze their eggs. She makes the case that corporate claims to "stop time" or "freeze fertility" while stopping short of explicit assurances - still cross the line of informed consent and truthful advertising. Her analysis of this landscape adds critical evidence to calls for transparency in the multi-billion-dollar market for reproductive services.

The second point is that red tape could make reproductive services available to fewer people. Just fifteen states mandate insurance coverage to treat infertility. ${ }^{14}$ Freezing eggs already costs anywhere from $\$ 6,000$ to $\$ 20,000$ for just one cycle, plus another $\$ 500 /$ year for storage, with total costs to make a baby this way around $\$ 100,000-$ at a time when median household income is half that. ${ }^{15}$ If transparency requirements would raise prices, what's an acceptable tradeoff with affordability?

Limits on access are not spread evenly, either. Recent surveys suggest just $4 \%$ of women who froze their eggs are African American, despite their higher rates of infertility. ${ }^{16}$ Insurance coverage and truth in advertising are important first steps. But these disparities probably also owe to in part egg freezing ads and brochures about "maternal 'empowerment' that center on elite white women" and shame or isolate women of color through marketing that leaves out their images and stories. ${ }^{17}$ The promotion of fertility services should be honest, yes, but inclusive too.

\section{Note}

The authors have no conflicts to disclose.

\section{References}

1. D. Friedman, "Perk Up: Facebook and Apple Now Pay for Women to Freeze Eggs," NBC Nerws, October 14, 2014, available at <https://www.nbcnews.com/news/us-news/perk-facebook-apple-now-pay-women-freeze-eggs-n225011> (last visited October 9, 2020).

2. S. Mohapatra, "Using Egg Freezing to Extend the Biological Clock: Fertility Insurance or False Hope" Harvard Law छ Policy Review 8, no. 2 (2014): 382-341.

3. S.E. Richards, "What Happened to All of Those Frozen Eggs?" New York Times, December 21, 2019, available at <https:// www.nytimes.com/2019/12/21/opinion/sunday/egg-freezingnumbers.html > (last visited October 9, 2020).

4. M.J. Bayefsky, "Legal and Ethical Analysis of Advertising for Elective Egg Freezing," Journal of Law, Medicine $\Xi 5$ Ethics 48, no. 4 (2020): 748-764.

5. See, E.g., J. Carbone and J.L. Madeira, "Buyers in the Baby Market: Toward a Transparent Consumerism," Washington Law Review 91, no. 1 (2016): 71-107, at 77-79.
6. J. Hawkins, "Selling ART: An Empirical Assessment Of Advertising On Fertility Clinics' Websites," Indiana Law Journal 88, no. 4 (2013): 1147-1179, at 1169 .

7. N. Wartik, "Making Babies: The Boom in the Infertility Business is Raising Hopes, and Increasing Criticism," Los Angeles Times Magazine, March 6, 1994, at 18, 43, available at $<$ https://www.latimes.com/archives/la-xpm-1994-03-06-tm30688-story.html> (last visited October 9, 2020).

8. D.C. Schmittlein and D.G. Morrison, "A Live Baby or Your Money Back: The Marketing of In Vitro Fertilization Procedures," Management Science 49, no. 12 (2003): 1617-1635, at 1631

9. 42 U.S.C. $263 \mathrm{a}-1$ et. seq. (2012).

10. American Medical Association Council on Ethical \& Judicial Affairs and Council on Scientific Affairs, Issues of Ethical Conduct in Assisted Reproductive Technology 2 (1996).

11. J.E. Brody, "I.V.F.'s Misleading Promise to Those over 40," New York Times, October 17, 2016, available at <http://www. nytimes.com/2016/10/18/well/the-misleading-promise-of-ivffor-women-over-40.html> (last visited October 9, 2020).

12. Industry guidelines are supposed to be required for professional membership, but studies show that most clinics face no penalty for claiming without evidence that they pregnancy success rates are "superior" or "among the best." W.K. Miller, "Assumption of What? Building Better Market Architecture for Egg Donation," Tennessee Law Review 86, no. 1 (2018): 33-71, at 51-52; M.E. Abusief, M.D. Hornstein, and T. Jain, "Assessment of United States Fertility Clinic Websites According to the American Society for Reproductive Medicine (ASRM) / Society for Assisted Reproductive Technology (SART) guidelines," Fertility and Sterility 87, no. 1 (2007): 88-92.

13. On the right, for example, many are anxious about implicitly endorsing technologies that separate sex from reproduction. On the left, meanwhile, others are wary of opening the door to new forms of reproductive restrictions on who gets to form families and how. See D. Fox, Birth Rights and Wrongs (Oxford, 2019), at 29-30.

14. S. Mohapatra, "Fertility Preservation for Medical Reasons and Reproductive Justice," Harvard Journal on Racial छ Ethnic Justice 30, no. 1 (2014): 193-225, at 206 (2014).

15. H. Hoffower, "More Women are Freezing their Eggs to Delay Having Kids - But the Process Costs Thousands of Dollars and Still Might not Work. Here's What You Should Know." Business Insider, January 15, 2020, available at <https:// www.businessinsider.com/how-much-does-it-cost-to-freezeyour-eggs-2020-1> (last visited October 9, 2020).

16. American Society for Reproductive Medicine Access to Care Summit, (September 10-11, 2015) available at $<\mathrm{https://www.}$ asrm.org/globalassets/asrm/asrm-content/news-and-publications/news-and-research/press-releases-and-bulletins/pdf/ atcwhitepaper.pdf> (last visited October 9, 2020).

17. R. Allen, Is Egg Freezing Only for White Women?, Nerw York Times, May 21, 2016, available at <https://www.nytimes. com/2016/05/22/opinion/is-egg-freezing-only-for-whitewomen.html?smid=tw-share $>$ (last visited October 9, 2020); 
R. Ceballo, E.T. Graham, and J. Hart, "Silent and Infertile: An Intersectional Analysis of the Experiences of Socioeconomically Diverse African American Women With Infertility, Psy- chology of Women Quarterly 39, no. 4 (2015): 497-511, available at <https://doi.org/10.1177/0361684315581169> (last visited October 9, 2020). 
Copyright of Journal of Law, Medicine \& Ethics is the property of Sage Publications Inc. and its content may not be copied or emailed to multiple sites or posted to a listserv without the copyright holder's express written permission. However, users may print, download, or email articles for individual use. 